\title{
LLNL Operations/Building Screening Report for Initial Hazard Classification Building 518/518A
}

\author{
C. E. Mathews
}

July 21, 2000

U.S. Department of Energy

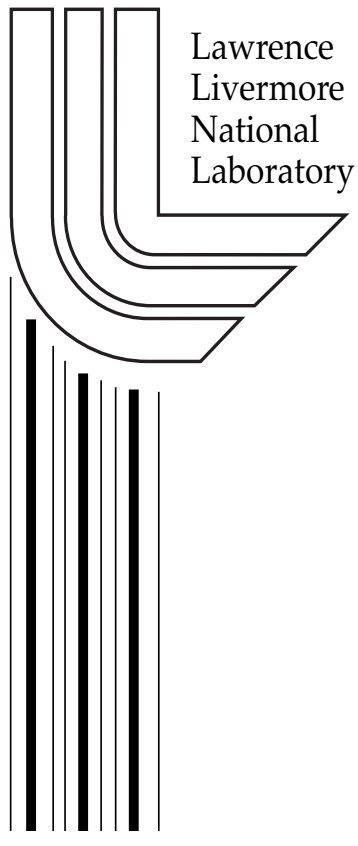




\section{DISCLAIMER}

This document was prepared as an account of work sponsored by an agency of the United States Government. Neither the United States Government nor the University of California nor any of their employees, makes any warranty, express or implied, or assumes any legal liability or responsibility for the accuracy, completeness, or usefulness of any information, apparatus, product, or process disclosed, or represents that its use would not infringe privately owned rights. Reference herein to any specific commercial product, process, or service by trade name, trademark, manufacturer, or otherwise, does not necessarily constitute or imply its endorsement, recommendation, or favoring by the United States Government or the University of California. The views and opinions of authors expressed herein do not necessarily state or reflect those of the United States Government or the University of California, and shall not be used for advertising or product endorsement purposes.

This work was performed under the auspices of the U. S. Department of Energy by the University of California, Lawrence Livermore National Laboratory under Contract No. W-7405-Eng-48.

This report has been reproduced directly from the best available copy.

Available electronically at http://www.doc.gov/bridge

Available for a processing fee to U.S. Department of Energy

And its contractors in paper from

U.S. Department of Energy

Office of Scientific and Technical Information

P.O. Box 62

Oak Ridge, TN 37831-0062

Telephone: (865) 576-8401

Facsimile: (865) 576-5728

E-mail: reports@adonis.osti.gov

Available for the sale to the public from

U.S. Department of Commerce

National Technical Information Service

5285 Port Royal Road

Springfield, VA 22161

Telephone: (800) 553-6847

Facsimile: (703) 605-6900

E-mail: orders@ntis.fedworld.gov

Online ordering: http://www.ntis.gov/ordering.htm

OR

Lawrence Livermore National Laboratory

Technical Information Department's Digital Library

http:/ / www.llnl.gov/tid/Library.html 


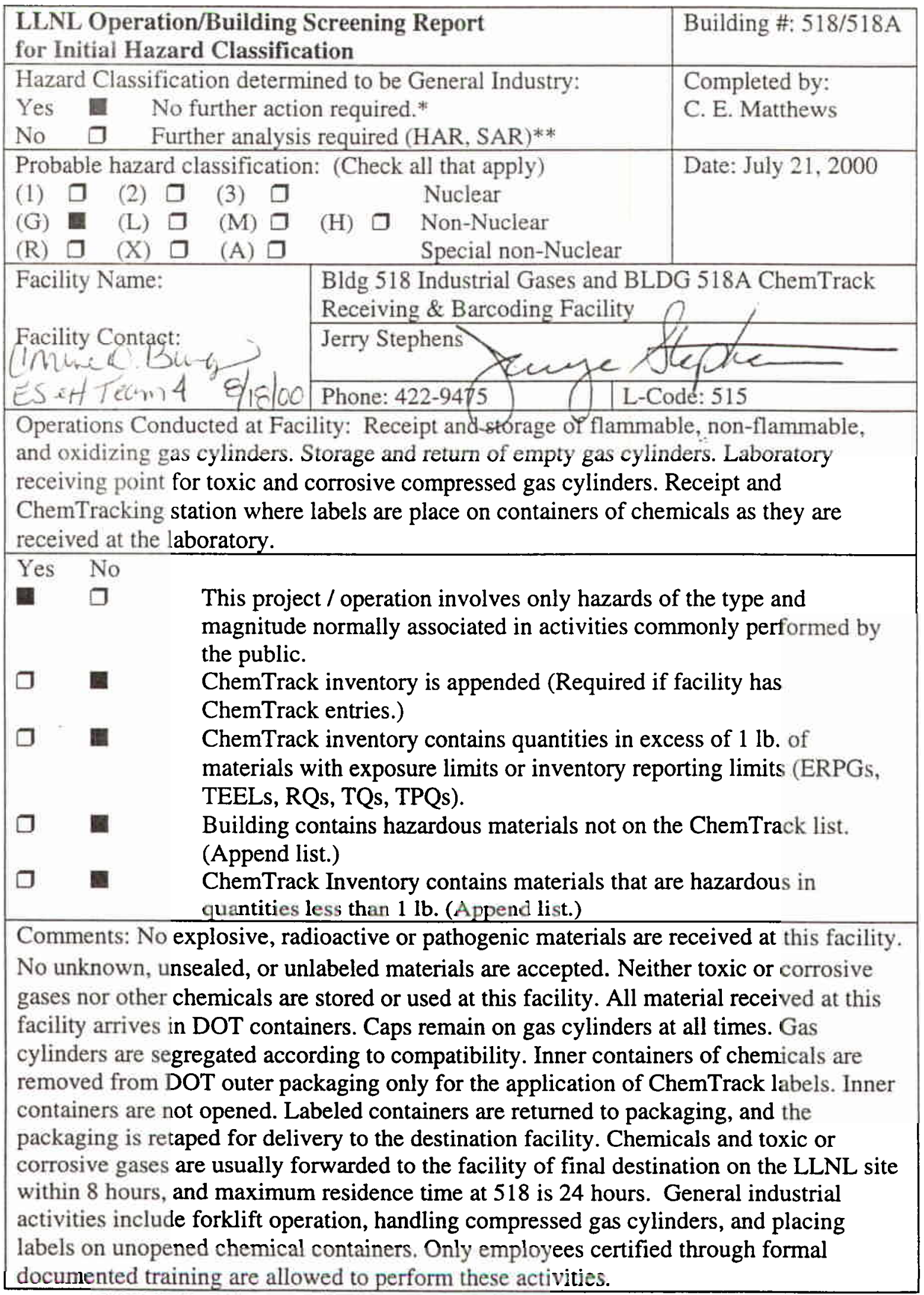
* cc: (1) Building file
** Also cc:
Facility Contacts and SARA File 


\section{HAZARD SCREENING CHECKLIST FORM}

Facility No. 518

Screened by: C. Matthews (ANL) Name/Affiliation
Dates Performed $6 / 28 / 00$

Facility Manager

Yes No

1. Facility Manager and appropriate program and support personnel consulted?

2. Facility inspection complete?

3. Facility personnel interviewed and FSPs, OSPs, or IWSs reviewed?

4. List other documents reviewed: 40 CFR 302.4 and 355, and 29 CFR 1910.119

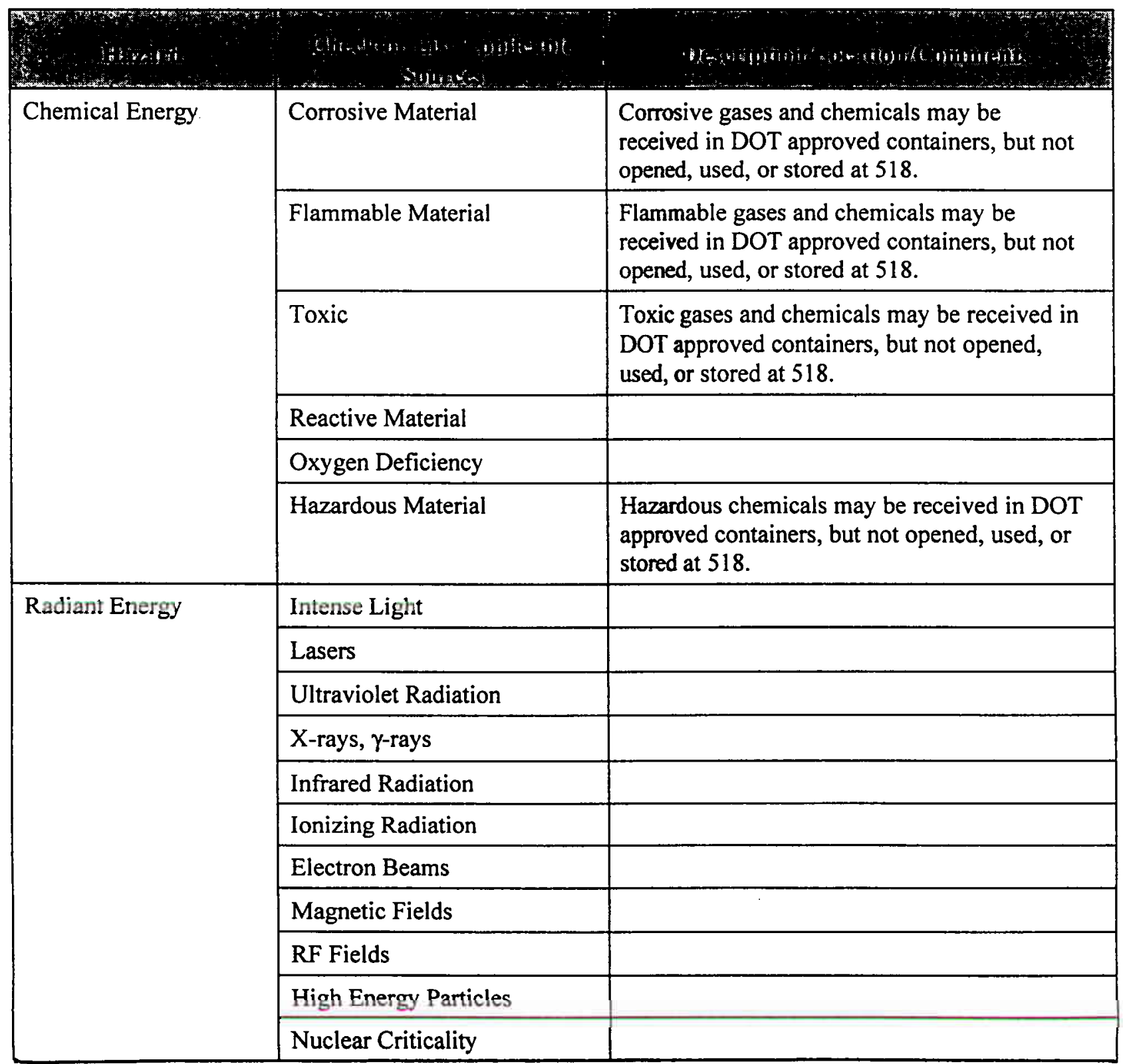




\begin{tabular}{|c|c|c|}
\hline Hazard & $\begin{array}{l}\text { Check or List Applicable } \\
\text { Sources }\end{array}$ & Description/Location/Comments \\
\hline \multirow[t]{7}{*}{ Electrical Energy } & High Voltage $(>50 \mathrm{~V})$ & Electrical outlets and typical equipment \\
\hline & Very High Voltage $(>600 \mathrm{~V})$ & \\
\hline & Capacitors & \\
\hline & Transformers & \\
\hline & Batteries & \\
\hline & Exposed Conductors & \\
\hline & Static Electricity & \\
\hline \multirow[t]{5}{*}{ Kinetic Energy } & Pulley, Belts, Gears & \\
\hline & Shears, Sharp Edges & \\
\hline & Pinch Points & \\
\hline & Mass in Motion & \\
\hline & Motor Vehicles & Forklifts, transport vehicles \\
\hline \multirow[t]{4}{*}{ Potential Energy } & Falling & \\
\hline & Lifting & Forklifts \\
\hline & Tripping, Slipping & \\
\hline & Earthquakes & 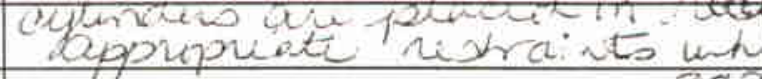 \\
\hline \multirow[t]{3}{*}{ Thermal Energy } & High Temperature & 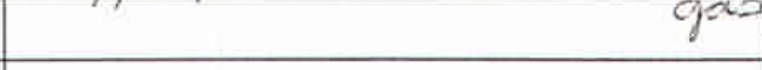 \\
\hline & Cryogenic Materials & $\begin{array}{l}\text { DOT approved dewars of cryogenic liquids are } \\
\text { received, but not stored or used at } 518 \text {. }\end{array}$ \\
\hline & Fire or Open Flames & \\
\hline \multirow[t]{3}{*}{ Pressure Energy } & $\begin{array}{l}\text { Pressurized or Confined } \\
\text { Gases }\end{array}$ & $\begin{array}{l}\text { DOT approved cylinders of compressed gases } \\
\text { are received at } 518 \text {. Flammable, non- } \\
\text { flammable and oxidizing gases are stored but } \\
\text { not used at } 518 .\end{array}$ \\
\hline & Explosives & \\
\hline & Noise & \\
\hline \multirow[t]{2}{*}{ Biological Energy } & $\begin{array}{l}\text { Pathogens (virus, bacteria, } \\
\text { etc.) }\end{array}$ & \\
\hline & Allergens & \\
\hline Other (list or attach) & & \\
\hline
\end{tabular}

Note: Check box here if supplemental checklists were used for hazard screening and attach supplemental checklists to this form. 


\title{
CHECKLIST FOR STRUCTURES, SYSTEMS, AND COMPONENTS (SSC) THAT ARE RELATED TO SAFETY IN GI FACILITIES
}

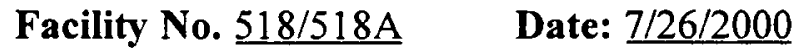

Use this checklist to identify GI facility structures, system, and components that function to protect employees, the facility, and the environment. It is important to note that this checklist is not all-inclusive. Feel free to add additional SSCs and comments under the "other" category below.

1. Life Safety/Fire Protection:

$\underline{X}$ Fire Detection/Alarm Systems

$\begin{array}{ll}- & \text { Fire Suppression Systems } \\ & \text { Flammable Liquid Storage Cabinets } \\ & \text { Fire Doors/Walls } \\ \mathrm{X} & \text { Evacuation Page }\end{array}$

2. Other systems to protect employees, the facility, and the environment:

Retention Systems (Tanks, Berms, Containments)

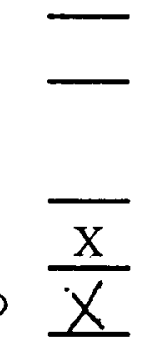

Standby Power Generators

Installed Special Detection/Alarm Systems (Oxygen Deficiency, Hydrogen, Radiation, etc.)

CDB $\frac{x}{x} \quad \begin{aligned} & \text { Emergency Showers/Eyewashes } \\ & \text { Seismic Restraints }\end{aligned}$

_ Fume Hoods

__ Negative Air Ventilation Systems

- HEPA Filtration

Interlocks

3. Other SSCs related to safety/Comments:

The 518/518A facility is bounded by a chain link fence and an electric gate to restrict foot and vehicle traffic.

The 518 facility does not have any freestanding cylinders; ail cylinders are restrained to prevent fromfalling 